\title{
TRANSINDIVIDUAL-TRANSVERSAL SUBJECTIVITY FOR THE POSTHUMAN SOCIETY
}

\author{
Jae-Hee Kim* \\ kimjh67@ewha.ac.kr
}

RESUMO O problema com o qual o "pós-humano" deve lidar é complexo: como alguém pode abraçar tanto a problematização e a construção antihumanística do sujeito humano pelo pós-estruturalismo e, ao mesmo tempo, conectar a capacidade de tecnociência à desumanização com a possibilidade de inventar uma subjetividade pós-humana? Considerações sobre póshumanização do humano devem expandir para além da ciborguezação baseada no fortalecimento da capacidade de individuos humanos, e existe a necessidade de uma mudança de paradigma para que possamos repensar e reconceitualizar o pós-humano dentro da rede relacional ontológica e sociopolitica trabalhando além da oposição do determinismo tecnocêntrico e do instrumentalismo humanocêntrico. Seres humanos foram produzidos na sociedade disciplinar na forma de "individuos" autodisciplinados e têm sido produzidos na sociedade de controle na forma de "dividuos" desindividualizados, respectivamente. Nesse caso, qual será a forma dos seres humanos na sociedade pós-humanista do lado de fora ou após a sociedade de controle, que ainda está por chegar? Neste trabalho, aponto as limitações de discussões sobre ciborguezação e examino o diagnóstico de Deleuze sobre a sociedade de controle baseada na tecnologia digital, argumento que podemos encontrar uma nova possibilidade para a subjetividade pós-humana no "relacionamento transindividual" de

* Ewha Womans University (Coreia do Sul). Artigo recebido em 08/06/2016 e aprovado em 17/08/2016.

KRITERION, Belo Horizonte, n 137, Ago./2017, p. 391-411 
Simondon complementado pela "transversalidade" de Guattari. Proponho que será possível que uma sociedade pós-humana seja produzida quando os relacionamentos transindividuais forem baseados na operação transdutiva das invenções tecnológicas, percebendo que a potencialidade comum natural seja atingida, e um alto grau de comunicação transversal que evite que a subjugação dessa coletividade seja mantido.

Palavras-chave Pós-humano, Simondon, Deleuze, Guattari, transindividual, transversalidade.

ABSTRACT The problem that the "posthuman" must cope with is complex: how can one embrace both anti-humanistic problematization and deconstruction of the human subject by post-structuralism and, at the same time, link the capacity of techno-science for de-humanization with the possibility for inventing posthuman subjectivity? Consideration of the posthumanization of the human must expand further from the cyborgization based on the strengthening of human individuals' capacity, and there is need of a paradigm shift for us to rethink and reconceptualize the posthuman within the ontological and sociopolitical relational networking beyond the opposition of technocentric determinism and humancentric instrumentalism. Human beings were produced in the disciplinary society in the form of self-disciplined "individuals" and have been produced in the control society in the form of de-individualized "dividuals," respectively. If so, then what will the form of human beings be in the posthuman society outside or after the control society, which has yet to arrive? In this paper, pointing out the limitations of discussions on cyborgization and examining Deleuze's diagnosis of the control society based on digital technology, I argue that we can find a new possibility for posthuman subjectivity in Simondon's "transindividual relationship" complemented by Guattari's "transversality." I propose that it will be possible for posthuman society to be produced when the transindividual relationships based on the transductive operation of technological invention realizing the common natural potentiality are realized, and a high degree of transversal communication that prevents the subjugation of this collectivity is maintained.

Keywords Posthuman, Simondon, Deleuze, Guattari, transindividual, transversality. 


\section{Introduction}

To which problem must the "posthuman" be considered an answer? There are largely two backgrounds to the emergence of the posthuman theme. One background is a situation in which, ever since poststructuralism attempted a critical deconstruction of traditional humanism and the human subject, finding a new subjectivity that does not regress to anthropo-individual-centric humanism has become urgent. From this point of view, the 'human being' is not the absolute, but merely a thing that is 'produced' in the relation of discursive powers constructed in particular historical situation: subjectivity as the reasonable and self-regulating individual of liberal humanism is nothing other than the effect produced by the formation and exclusion of the other. The other background is that the GNR Revolution (genetic engineering, nano-engineering, and robotics revolution) based on information technology has changed the form of the human and has dramatically risen as a condition of new subjectivization; the task of cyborgization, which combines in a single system the natural and the artificial, has been promoted in diverse fields. In addition, with the prospect of the hyper-connected society, the digital codes of computing technology are realizing universal communication networks, where the production, exchange, and use of information are possible between humans, between humans and objects, and between objects. A convergence of human and machine is one of the fundamental conditions for the transformation of the human and the transition of the human society. The de-humanizing process of humans and the technology-mediated ontological evolution raise a techno-politically important question in terms of praxis regarding whether, for us as "humans," it will lead to a path of yet another alienation and subjugation or of new subjectivization that will create the "posthuman."

Consequently, the problem that the "posthuman" must cope with is complex: how can one embrace both anti-humanistic problematization and deconstruction of the human subject by poststructuralism and, at the same time, link the capacity of techno-science for de-humanization and social transition with the possibility for inventing posthuman subjectivization? Based on such a problematics, I would like to examine critically models of the posthuman at the present stage and to search for possible alternatives.

The model of the "cyborg," the most popular representation of the posthuman, remains on the level of the strengthening of human individuals' capacity through mind-body transformation. This approach is insufficient for considering the well-balanced relationship between human and technology in order to overcome anthropo-individual-centric humanism and to produce a new subjectivity, and there is need of a paradigm shift for us to rethink and 
re-conceptualize the posthuman within the whole relational networking of ontological and sociopolitical dimensions concerning technology. In relation to this, Deleuze's control society, which takes over Foucault's anti-humanism and disciplinary society, is useful because it shows how the IT society that accelerates an antropo-individual-centric liberal humanism produces fragmented dividuals deprived of the ability of solidarity but leads us in a different direction of thinking about posthumanization, the formation of a new subjectivity, and the prospect of a posthuman society.

Pointing out the limitations of discussions on cyborgization and considering Deleuze's diagnosis of the control society based on digital technology, I wish to argue that we can find a new possibility for posthuman subjectivity in Simondon's "transindividual relationship" complemented by Guattari's "transversality." Simondon suggests a new model of subjectivity produced by the recovery of communication going through mutually incompatible and disparate things, an ensemble of nature-technique-human, by showing the possibility of an ontological genesis of transindividual relations among individuals or dividuals that realize their common natural potentiality; the realization of transindividuality would be impossible if not for the balanced relation between technologies and the human that is beyond the opposition of technocentric determinism and humancentric instrumentalism. In my view, therein lies the possibility for a posthuman subjectivity that does not reduce to the cyborg model focused on the enhancement of the human individual capacity and that cuts across the techno-utopian fantasy based on the hyper-connectivity of digital coding and techno-nihilism of dividuals produced by the control society.

\section{Limitations of the Cyborg Model}

According to Max More, "By thoughtfully, carefully, and yet boldly applying technology to ourselves, we can become something no longer accurately described as human - we can become posthuman" (2013, p. 4). The transhumanism consists of "[p]hilosophies of life (such as extropian perspectives) that seek the continuation and acceleration of the evolution of intelligent life beyond its currently human form and human limitations by means of science and technology, guided by life-promoting principles and values" and is "[t]he intellectual and cultural movement that affirms the possibility and desirability of fundamentally improving the human condition through applied reason, especially by developing and making widely available technologies to eliminate aging to greatly enhance human intellectual, physical, and psychological capacities" (2013, p. 3). As "trans-humanism," transhumanism goes beyond Enlightenment humanism in 
its "means and purposes" and advocates "transhuman-ism" as "trans-human" that transcends the "human" of this traditional humanism. The "posthuman" of transhumanism signifies a "more improved and evolved human" that has overcome the less desirable aspects and limitations of the physico-biological conditions of humans. Their posthuman need not undergo illness and aging and can possess broader physical abilities and morphological freedom, greater cognitive abilities and improved emotions. This subject expands the capacity of the "human" by effectively using state-of-the-art technoscience and seeks to realize the perpetual progress of the "human". If so, then can this enhanced human of transhumanism indeed present appropriate answers to the problems that the "posthuman" must cope with?

I think that in transhumanism, the de-humanization effect of technoscience still remains within the magnetic field of humanism, which has been deconstructed by poststructuralist anti-humanism. First, an optimistic preference for stateof-the-art technoscience implies both an instrumentalistic understanding of technology and a technologically deterministic attitude. This presupposes both an anthropocentric attitude to technology and liberal humanism, which justified the conquest of nature and the enslavement of machines for individuals' freedom. Next, the human enhancement model implies functionalistic physicalism, according to which biological neurons can be replaced with artificial objects possessing identical cognitive functions. It is not necessary to insist on the biological body that one was born with to perform cognitive functions, and, as Hans Moravec (1990) and Ray Kurzweil (2005) claim, it will be possible also to "upload" one's mind "inside" a computer, a non-biological substance. Consequently, the posthuman subject can be represented as a disembodied cyborg or as a cyborg, like in the Japanese comic book series/animated films "Ghost in the Shell", which can freely replace its body. Katherine Hayles criticizes the above scholars' Cartesian dualism, arguing that the biological body cannot be reduced to abstract information codes (1999). Max More, in turn, rebuts this: "Those critics are confusing dualism with functionalism" (2013, p. 7). However, in that it argues for "replaceability with an artificial body," which implies the erasability of the biological body, the functionalistic cyborg model can be said to willingly embrace Cartesian logocentrism, which underestimates the body. Finally, transhumanists seek to eliminate biological, psychological, cultural, and political "constraints on our progress and possibilities as individuals, as organizations, and as a species" (More, 2013, p. 5). This desire, which seeks permission for the "free realization of self-transformation with respect to the body" for infinitely extensible life, more intellect and wisdom, and emotional and psychological improvement, presupposes strong anthropocentrism and 
liberal individualism. There is no consideration for "sub-human or non-human others," who were excluded in the social and political dimensions. Consequently, I think that the enhanced human of transhumanism is not an adequate model of posthuman subjectivity for overcoming the anthropo-individual-centric humanism.

Katherine Hayles criticizes that the cyborg model presupposes liberal humanism and conceals the downfall of the liberal human subject under the apocalyptic fear that the human race will become extinct due to posthumanization: instead, she presents, as a new model of the posthuman, the union of humans with intelligent machines based on embodied entity. "As you gaze at the flickering signifiers scrolling down the computer screens, no matter what identifications you assign to the embodied entities that you cannot see, you have already become posthuman" (Hayles, 1999, p. xiv).

If the "human" of liberal humanism signifies a possessor of one's own abilities (will, desire, consciousness, etc.) as an individual free from others' will and an autonomous individual of a closed border who is self-organized independent of the environment, then " $[\mathrm{t}]$ he posthuman subject is an amalgam, a collection of heterogeneous components, a material-informational entity whose boundaries undergo continuous construction and reconstruction" (Hayles, 1999 , p. 3). This posthuman subject replaces the autonomous will of the cogito with "distributed cognition," a body seen as a support system for the mind with "embodiment," and the human subject who dominates over and controls nature with "a dynamic partnership between humans and intelligent machines" (Hayles, 1999, p. 288).

Hayles criticizes the "cyborgization of the human" based on the disembodiment strengthened in the development process of cybernetics. The focus of Hayles' criticism lies in the concept of "dematerialized information," which has made the cybernetic system possible, and the liberal humanism that this concept implies. According to her, in cybernetics, information consists of mathematical logical patterns differentiated from a physical entity: as life forms and machines have become identical "information processing systems," differences in embodied materiality have been erased and the bodies of life forms have become abstract information patterns instead of physical presences: this concept of information has made possible the claim that both Moravec's computer, inside which the mind has been downloaded, and the Puppet Master from "Ghost in the Shell" are "living beings" even without bodies and based solely on information patterns. Hayles criticizes that the concept of dematerialized information not only is a reflection of form-centered Platonism but also has made possible the erasure of marks of difference (gender, race, ethnicity, etc.) 
as well as of the physical body, thus universalizing Cartesian rationalism and strengthening the subjectivity of liberal humanism based on it.

To supplant the disembodied cyborg model, Hayles stresses the reality of material embodiment, which cannot be reduced to abstract information, based on the embodiment theory of neo-cybernetics. She distinguishes between the body and embodiment, between inscription and incorporation, and claims that whereas the body and inscription assume conceptual abstraction and universal normativity, which corresponds to the Platonic form, embodiment and incorporation preserve particularity and differences that are physically realized in concrete temporal-spatial contexts. Consequently, "[w]hereas the body can disappear into information with scarcely a murmur of protest, embodiment cannot, for it is tied to the circumstances of the occasion and the person" (Hayles, 1999, pp. 197-198). Similarly, incorporation, unlike inscription, which represents abstract concepts, signifies expressions through direct motions and actions in particular contexts. For example, learning to swim is impossible with theoretical knowledge alone; one must enter the water and flail around. Likewise, Hayles stresses the embodiment and incorporation of life forms leading concrete lives amidst interactions with the environment and argues that the posthuman is not a disembodied cyborg, but a subject embodied and incorporated in a manner different from that of the human in a new technological environment. Consequently, if the cyborg model identifies human subjectivity with consciousness and consciousness with cognition as a logical function and, in the end, fuses humans and computers, Hayles argues that, in consideration of the concrete differences of embodiment that cannot be abstracted into information patterns, the identification of humans and intelligent machines is impossible. Criticizing Moravec, who claims that life forms, based on proteins, will be supplanted by those based on silicon (Moravec, 1990, pp. 1-5), Hayles argues that posthumanization does not directly translate into the extinction of the human species and the computerization of humans and that the posthuman subject does not necessarily have to be a cyborg. ${ }^{1}$ Hayles finds the characteristics of the posthuman not in whether non-biological elements exist

1 "But the posthuman does not really mean the end of the humanity. It signals instead the end of a certain conception of the human, a conception that may have applied, at best, to that fraction of humanity who had the wealth, power, and leisure to conceptualize themselves as autonomous beings exercising their will through individual agency and choice. What is lethal is not the posthuman as such but the grafting of the posthuman onto a liberal humanist view of the self. When Moravec imagines 'you' choosing to download yourself into a computer, thereby obtaining through technological mastery the ultimate privilege of immorality, he is not abandoning the autonomous liberal subject but is expanding its prerogatives into the realm of the posthuman. Yet the posthuman need not be recuperated back into liberal humanism, nor need it be construed as antihuman" (Hayles, 1999, pp. 286-287). 
but in the way in which subjectivity is constructed and presents as the model of the posthuman subject a "distributed cognition system," where human agents and in-human or non-human agents operate together based on the physical structures of embodiment. As with John Searle's famous "Chinese Room," the posthuman subject lives on in association with countless intelligent machines in an environment established by computer information science and technology. In other words, based on complex computational infrastructures, the technical distribution of cognition adequately posthumanizes humans even without including the transformation of the biological body.

Hayles' embodied-distributed posthuman model seems to "go beyond" liberal humanism, considering subjectivity within "human-nonhuman networks" that cannot be reduced to cyborgs. However, it is questionable whether this is indeed so. First, although the condition of subjectivization has been transferred from the "dematerialized cogito" to "material embodiment," the "embodied and distributed subject" has only shifted the role of subjectivity played by the cogito to physical sensomobility and is still guaranteed human individuals' self-identity from its embodiment (i.e., material embodiment extended to the partnership between living bodies and intelligent machines). Consequently, it remains to be seen how Hayles' posthuman, which is "material-informational entity," can produce posthuman subjectivity that will transcend the individualism of liberal humanism, with this "embodied and distributed cognition" as the means. Next, when the posthuman is defined as a "dynamic partnership between humans and intelligent machines," it is necessary to clarify further the relationship of "embodiment and information" presupposed by that "partnership." The differences between "dematerialized information" and "embodied entity that cannot be informationalized" separate intelligent machines and human life forms, view the relationship between machines and humans from the human gaze, and, in the end, can return to the classical cyborg image of anthropocentric humanism, of humans who extend freedom by using machines.

In short, as shown above, the transhuman, as the enhanced human and the embodied-distributed posthuman had their limits in that they considered the relation between technology and human only in term of anthropo-individualcentric humanism. I think that going beyond the thinking of cyborgization surrounding the opposition between disembodiment and embodiment of human individual mind-body, makes it is necessary to re-approach the synergic relationship between human and technology in the light of a more fundamental and holistic viewpoint that contemplates a condition of production for the posthuman subjectivity beyond the anthropo-individual-centric humanism. 


\section{The Controlled Dividuals of Deleuze}

In "On the Death of Man and Superman," Deleuze said that the manform as a new form that is neither God nor man, which would come into place after "the death of man" based on the analysis of Nietzsche-Foucault, would be "the superman" produced by entering into a relation with "forces of silicon which supersedes carbon, or genetic components which supersede the organism, or agrammaticalities which supersede the signifier" (1988, pp. 131-2); the potential of silicon that builds up the future form of man results from the "third-generation machines, cybernetics and information technology" (1988, p. 131). And in "Postscript on the Societies of Control" (Deleuze, 1995) he said that such a digital computing environment indicates entry into the control society. In the control society, the qualitative complexity of both human lifestyles and social relationships has been simplified into quantitative data, which are calculable and indiscriminately divisible; previously capable of action on their own both singularly and together, "individuals" have turned into de-individualized "dividuals," whose collective resistance has been spent. The scientific and technological capacity of connection and communication merely contributes to the production and control of dividuals within the movements of capitalism, which simultaneously de-territorializes and re-territorializes, decodes and axiomatizes. Then, in short, is this control society of dividuals - which has such "machines of a third type" as its own technological condition, the society of post-humans that the human race seeks to arrive at after the so-called "death" of God and humans alike - neither a God-centered society of sovereignty nor the disciplinary society of individual-centric humanism?

It is doubtful whether "Superman" and "Dividual" can be considered to be identical, although they have in common the $3^{\text {rd }}$ technology, that is, information technology as a condition of their production, for the same technological condition is creating the different outcomes of positive construction (superman) and negative deconstruction (dividual) of capabilities. Deleuze didn't offer any further arguments about the forms and prospects of superman as a post-human in the former paper, and opened a possibility of escape outside the control society in the latter one; maybe the form of superman to arrive could be found in the one after the controlled dividuals. However, I think that we can meet the possibility of a leap from Dividual to Superman, the genetic condition of posthuman in not so much Deleuze as Simondon. Nevertheless, there is no doubt that Deleuze's analysis on the control society as a social assemblage that has information technology as one of its components and on dividuals as its outcome is a sharp diagnosis for the shift of paradigm, for it informs us of 
the way in which we should investigate on the relation between the human and current technology and on the posthuman subjectivity based on it.

Deleuze diagnosed that contemporary society was no longer the disciplinary society but had entered the stage of the control society. Having ushered in the era of humanism in the $19^{\text {th }}$ century and the first half of the $20^{\text {th }}$ century, the disciplinary society produced self-disciplined "individuals" who conformed to social systems and power through the broad organization of panoptic enclosure spaces, including family, school, hospital, factory, and prison, and through systematic drills carving discipline into the body, as Foucault so brilliantly analyzed. In the disciplinary society, different internments or spaces of enclosure through which the individual passes were independent variables. Individuals were molded as students at schools and as laborers at factories according to the code of conduct of each space, and the individual as a single body was able to form the mass, which at any rate could be either subordinate or resistant. However, in the control society, which began to be active in earnest during the latter half of the $20^{\text {th }}$ century, different control mechanisms are inseparable variations. All activities in each sphere are never complete or separate but always coexistent as metastable states, only and continuously being modulated and transformed. Having replaced the factory, the corporation constantly presents the brashest rivalry as a healthy form of emulation, an excellent motivational force that opposes individuals against one another and runs through each, dividing each within. The modulating principle of "getting paid for results" (Deleuze, 1995, p. 179) forces perpetual self-improvement training on individuals. Previously indivisible entities, "individuals" turn into an abstract quantity of infinitely divisible "dividuals" - "Dividuals are the abstract digital products of datamining technologies and search engines and computer profiling, and they are the profiled digital targets of advertising, insurance schemes and opinion polls" (Bogard, 2009, p. 22). What best represent the mechanisms of this control society are none other than "digital codes". "Disciplinary societies have two poles: the signature standing for individuals, and numbers or places in a register standing for their position in a mass. [...] In control societies, on the other hand, the key thing is no longer a signature or number but a code: codes are passwords, whereas disciplinary societies are ruled by precepts. The digital language of control is made up of codes indicating whether access to some information should be allowed or denied. We're no longer dealing with a duality of mass and individual. Individuals become 'dividuals,' and masses become samples, data, markets, or 'banks'” (Deleuze, 1995, pp. 179-180, emphasis original).

In fact, in Anti-Oedipus, "codes" signify the universal functions of the social machine. Coding the flows of desire is the social machine's supreme task. "To 
code desire - and the fear, the anguish of decoded flows - is the business of the socius" (Deleuze and Guattari, 1983, p. 139). In this respect, signatures and registration numbers in the disciplinary society, too, are types of social coding. By contrast, in "Postscript on the Societies of Control," "codes" are the functions of specific technical machines constituting the control mechanism and, in particular, signify access to and blockage from information. But for Deleuze, as far as it goes, the technology was more social than "technical" and more a component of the social machine as a social assemblage than an independent condition determining the form of society. Deleuze's interest lay not so much in the functional operation of technical machines themselves but in their effect on the operation of the social machine itself. "The old sovereign societies worked with simple machines, levers, pulleys, and clocks; but recent disciplinary societies were equipped with thermodynamic machines presenting the passive danger of entropy and the active danger of sabotage; control societies function with a third generation of machines, with information technology and computers, where the passive danger is noise and the active, piracy and viral contamination" (Deleuze, 1995, pp. 179-80). While the dynamic machines of the disciplinary social machine can threaten social production due to the natural abrasion and disintegration that lead to thermodynamic equilibrium ("passive danger of entropy") and as a means of labor disputes that delay production by destroying the mechanical facilities in factories ("active danger of sabotage"), the computers of the control social machine can bring about both a "passive danger," where control systems are stopped by jamming, and an "active danger," where control systems can be penetrated by piracy and the introduction of viruses. I think that in these very "dangers" noted by Deleuze, it will be able to find the possibility of fleeing to the outside of the control society. However, he did not provide further, more in-depth analysis of this.

In my view, what Deleuze focused more on in diagnosing the transition from the disciplinary society to the control society were not the developmental types of technical machines but the corresponding changes in the types of capitalism: "This technological development is more deeply rooted in a mutation of capitalism" (1995, p. 180). The $19^{\text {th }}$ century capitalism was concentrative, proprietorial, and directed toward production, whereas the $20^{\text {th }}$ century capitalism is dispersive and directed toward such meta-production as sales or markets: if capitalism in the disciplinary society consisted of working hard to create objects and selling them to earn money, capitalism in the control society prompts one to use money by obtaining loans, with future success as a surety, and pay loan interest. The change from the gold standard system to the credit money system modifies lifestyles and ways of forming relationships with others. Capitalism in 
the control society is no longer "a man confined" and, instead, creates "a man in debt" (Deleuze, 1995, p. 181). However, I think that such changes are in fact merely capitalism's ways of overcoming and transforming itself. In other words, because it still occurs within currency capitalism, the transition from the disciplinary society to the control society is not discontinuous. And especially, because such transition occurs within the same "humanism," which is "cynical yet pious" (Deleuze; Guattari, 1983, p. 225) regarding capital, the transition is not discontinuous either. Furthermore, as stated in Anti-Oedipus, by nature, capitalism decodes and de-territorializes all flows of desire and, at the same time, recodes and re-territorializes into its own axiomatic system. In the capitalist society, all the decoded flows including the flows of scientific and technical codes serve the profit and purposes of the capitalist system: "The strength of capitalism indeed resides in the fact that its axiomatics is never saturated, that it is always capable of adding a new axiom to the previous ones" (Deleuze; Guattari, 1983, p. 250). If so, then in order to transform into the posthuman society from the dividual society, where can we find the leak locations of the control society, whose subcomponents are the technical machines of computers and financial capitalist machines? Can the lines of flight facing outside the control society be found indeed?

In fact, Deleuze acknowledged the ineptitude of labor unions, valid in the disciplinary society, but no longer operating in the control society. In addition, he was also skeptical about Antonio Negri's prediction that the control society would lead to forms of resistance that might reopen the way, as Communism understood the "transversal organization of free individuals" (Deleuze, 1995, p. 175). Because speech and communication had been corrupted by capital, and they had nothing to do with minorities speaking outside, Deleuze only stated, "We've got to hijack speech. Creating has always been something different from communicating. The key thing may be to create vacuoles of non-communication, circuit breakers, so we can elude control" (1995, p. 175). Just as soldering alone is insufficient and the entire system must be replaced if it breaks down frequently, producing and accelerating crises in diverse points of the control society machine through a variety of experiments involving encounters with the outside would be the Deleuzian solution regarding transition outside the control society. In fact, for Deleuze, the abstract machine of control was intrinsically neither nihilistic nor redemptive. He said that "It's not a question of worrying or of hoping for the best, but of finding new weapons" (1995, p. 178). Then, what will be the "new weapons" that would make possible accelerating the process of decoding and de-territorializing and thus functioning as "circuit breakers" inside the control society without being captured by capitalism's 
re-territorialization and axiomatization? If communication is controlled by digital codes and financial capital, then how can new assemblages and social solidarity be created?

\section{The Transindividual Relationship of Simondon}

Deleuze's interest lay in showing the crisis of human lifestyle through the transition from the disciplinary society to the control society, so he did not deeply ponder the capacity of new technology itself, which at once constitutes and can deconstruct the control society. However, demonstrating a creative and non-cybernetic understanding of Information Technology omitted in Deleuze, Simondon presented the ontological possibility of the generation of the transindividual relationship that can newly organize the potentials of the enervated dividuals. This "transindividual relationship" as a new model of posthuman subjectivity is base on actualization of the "pre-individual potential" that is transported by "technical objects."

According to Simondon's individuation theory, the individual is a product of individuation and must be considered not as independent entity but relational reality inseparable from the milieu. All kinds of the forms of individual, including humans and machines, are systems individuated in their relationship with the entire environment, which is the basis for their existence, and what are important are not the homeostasis, closure, and autonomy of those systems, but "metastability." Individuation is an ontogenetic operation where pre-individual reality is divided into "individuals and associated milieus" and phase-shifted. The "Pre-individual" is not an unmoving, unchanging substance but is a meta-stable reality of "more-than-unity and more-than-identity" (Simondon, 2005, p. 26) charged with potential energy arising from internal differences. For example, the crystallization of supersaturated solutions, where the liquid phase is phaseshifted into the solid phase the moment a piece of crystal is placed in a solution, is a paradigm of individuation. The genesis of individuals such as crystals occurs as a resolution to resolve the internal conflict between incompatible and disparate realities (crystal seeds and supersaturated solutions). Different modes of individuation such as physical-, biological-, psycho-collective-, and technological individuation have been differentiated from within the common pre-individual reality as a way of resolving problems unresolved during previous individuation in a higher order, with the results of previous individuation as associated milieu. The potential energy of pre-individual reality is not exhausted by each individuation, and the individuals generated in each domain convey the pre-individual charge, becoming the conditions for the production of 
new individuation. The transductive operation of individuation based on the pre-individual explains how human beings individuated biologically make a "quantum leap" to the transindividual level, thus amplifying pre-individual reality upward. ${ }^{2}$ Here is presented a condition that allows individual-centrism to be overcome and a possibility for new subjectivization to be produced.

"Transindividuality" comes into being when metastable life forms produced through biological individuation execute new psychological-collective individuation to resolve problems that cannot be resolved on a biological level. By directly communicating across individuals, the pre-individual reality inhabiting individuals opens the possibility for problems that were irresolvable on an individual level to be resolvable on a transindividual level. Just as each link in a network communicates with other links without annulling its individuality, the transindividual signifies real collectivity that goes "through and beyond" individuals. If the "inter-individual" relations remains on the level of interaction among individuals separated in social coding and labor divisions, the "transindividual" relations are formed on the level of communication of significations based on the pre-individual reality that is not exhausted and inherent in individuals and is communicated amongst them through emotional empathy and internal resonance as it cuts across the existing social order. It is possible for humans to go beyond human individuality as life forms and to stand as subjects that realize in a new way the fundamental potential of nature inherent to them solely by associating with other individuals and forming a mutually cooperative ensemble. However, what organizes weak human individuals in a transindividual dimension, tying them together with the dynamic force of new individuation - that is none other than "technical objects."

In Du mode d'existence des objets techniques (1989[1958]), Simondon unearthed, as a condition of subjectivization, "technological activities" that had been veiled by the "labor-capital" frame and had remained in darkness. "Labor" is a concept that was appropriate only in eras when the relationship between

2 In fact, in Différence et répétition (1968), Deleuze severs the direct relationship between the pre-individual potential and the transindividual subject by identifying Simondon's "pre-individual" with the transcendental field of intensive differences and considering individuation on a dimension below that of physico-biological-organic organization. In addition, in Mille plateau (1980), Deleuze \& Guattari replace this pre-individual intensive field with a destratified-deterritorialized material flow of inorganic vitality, thus stressing the capacity for communication that cuts across all kinds of territories — strata - boundaries rather than the genetic potential of organic forms. So from the perspective of Deleuze \& Guattari, who emphasize becoming on the $n-1$ dimension to avoid dialectic unity that re-ties disparity and differences on a higher dimension, the "transductive unity" to a higher dimension possessed by Simondon's transindividuality can be unsatisfactory. However, I think that, to overcome the limitations of anthropo-individual-centric liberal humanism, "transindividual relationships based on pre-individual reality and technical objects" must be realized. In their reference about Simondon, Deleuze \& Guattari have not mentioned Simondon's concepts of "transduction" and "information" in particular. As for their insufficient reception of Simondon, a separate, lengthy discussion is necessary. 
technical objects and humans had continuity through physical interconnection and humans, as porters of tools, assumed the role of machines. Labor does not fall within transindividuality but within inter-individuality. In labor, human beings are not mobilized as "subjects" who are carriers of a pre-individual charge of nature that enables them to trans-individuate, and the inter-individual relations among the workers is merely a relation of the human species to nature. In this case, the transindividual is missed. By contrast, "technological activities" cannot be reduced to such labor and are a higher concept that can reestablish the relationship between humans and technical objects according to the level of technical individuals liberated from humans and of the technical ensembles. Technological activities themselves are operations that adjust communication and relationships among incompatible, heterogeneous, and disparate things. The human-machine ensemble in the technological activities presupposes not only a mutually cooperative relationship between humans and technical objects but also a mutually cooperative relationship among humans that communicates through these technical objects. "Through the intermediary of the technical object an inter-human relation that is the model of transindividuality is created" (Simondon, 1989, p. 248). ${ }^{3}$

Especially, the invention of new technical objects is a transindividual operation that carries not simply the capacity of outstanding individuals but the ontological charge of the pre-individual potential. What invents is not the individual but the "subject." This subject is a being that does not merely remain on the level of individuated being but knows how to realize the preindividual potential within itself through the invention of new structures for resolving problems. For Simondon, the inventor-technologist is, like the artist, a seeker at the margins of society who tries to establish a different relationship to the world, alternative points of connection that can ultimately create new worlds for us to experience. Just as Deleuze saw the individual hacker instead of collective labor unions as a war machine threatening the control society, for Simondon, the technician instead of the laborer played the role of a "pure individual" who, as a "singular point" (2005, p. 511) existing in this society, led closed communities towards change. This singular technician was a being very

3 For example, beyond the level of simple tools, excellent technological objects such as "iPhone" have produced a new collective relationship that realizes internal resonance (emotive sympathy like fraternity, friendship, and love) and communication of information traversing closed social orders and boundaries (social status, wealth or poverty, age, region, etc.). It was also a technological device called SNS that overcame political oppressions as blockades against informational communications and made solidarity of individuals possible in order to resolve their common problem (realization of political and economic democracy) as in the case of Tunisian Jasmine Revolution in 2010. 
threatening to society because he or she constantly sought to invent something new and to create new structures. If Deleuze left open the possibility of flight from the control society through circuit breakers as a single subject who refused to become dividuals, Simondon showed the possibility of new assemblages after the control society through the possibility of transindividual connection among these individuated single beings.

Furthermore, unlike Deleuze (or Deleuze-Guattari), who basically takes a neutral attitude toward the role of information technology as a component of the control society, ${ }^{4}$ Simondon thought that information technology would make cooperative operation possible between humans and machines, and provide a "new type of multitudes" and "collectivization" (1989, p. 100) capable of reflectively thinking about the purposiveness and organization of social systems through the establishment of symbolic systems shared by machines and humans. As Hayles points out, the cybernetic concept of information consists of dematerialized mathematical, logical patterns. According to Claude Shannon's classical model, Information is defined as a signal made up of $0 \mathrm{~s}$ and $1 \mathrm{~s}$, and the communication process is standardized as the S-C-R model (Source-encoding-Channel-decoding-Receiver): information comes into being when pre-established meanings (messages) are accurately transmitted from the source to the receiver through interference from noise. However, Simondon distinguishes information from form (as logical pattern) and redefines it as the changeability of forms, situating the conditions for the genesis of information in differences and disparity. Information is related to the metastable structuring of systems that form relationships of tension between pure coincidence (noise, meaninglessness) and absolute regularity (signals, meaning) and among disparate things. "Information is the tension between two disparate realities; it is the signification which will emerge when an operation of individuation discovers

Such differences in the attitude toward technology are demonstrated well in the concept of "machines." Simondon understood machines as technical objects realizing technicity on an individual level and, to reveal functional operation, the pure essence of machines, attempted methodologically (not in principle) a phenomenological analysis to eliminate the social, cultural, and economic factors added to them. By contrast, Guattari considered "a reconstruction of the concept of machine that goes far beyond the technical machine," pondered on "machinism in its totality, in its technological, social, semiotic and axiological avatars" (1992, p. 34). In addition, if Simondon understood the relationship between human and machines as a mutually cooperative one between individuals on an equal footing and argued for a "human-machine ensemble," Guattari thought that "technological machines of information and communication operate[d] at the heart of the human subjectivity, not only within its memory and intelligence, but within its sensibility, affects and unconscious fantasms" (1992, p. 4) and argued for a "human-machine assemblage." However, Simondon's technological machines and Guattari's ontological machines have one thing in common: they all are not self-identical closed systems with a feedback loop but metastable systems that keep the possibility for self-transformation and self-creation open amidst interactions with the outside. 
the dimension, according to which two disparate realities can be become a system" (Simondon, 2005, p. 31).

Simondon's concept of information does not consist of logical patterns or abstract signals and is not separated from materiality possessing potential energy. The communication of information is not the one-sided synchronization of the receiver with the source but is, in the interrelationship between the two, an action that triggers the new structuring of systems. If the cybernetic concept of information aims at maintaining the homeostasis and autonomy of systems through the transmission of signals and feedback correction, then Simondon's concept of information signifies the changeability of systems in their relationship with the environment. While the abstract universalization of the digital codes constructing the control society is based on the concept of cybernetic information, Simondon's concept of information provides the ground for digital technology to play the role of a war machine creating lines of flight outside the control society. Just as a phase-shift and crystallization occur in physical systems when the disparate realities of "structuralizing crystal seeds" and "supersaturated solutions as a meta-stable field" form a relationship, previously absent transindividual psycho-social collectives likewise are generated in social systems when signification is discovered among separated individuals. Information and communication are not merely technologies for constructing controllable networks through the shared symbolic language of computer coding but are transductive and ontogenetic operations that newly change the structures of a system by inventing, propagating, and amplifying new relations among incompatible and disparate things. Information technology networks can play the role of changing social systems through the creation of new affectiveemotional subconscious relations among members of society, with technical objects as the media.

In short, Simondon finds a possibility for humans to transcend their physicobiological conditions in both the existence of a "pre-individual potential" that inheres in human individuals as life forms and the "transductive capacity of technical objects," which prompt this potential to be communicated. In the cyborg model, the relationship between humans and machines is a relationship of "deficiency and supplementation," and mechanical elements supplement or supplant deficiencies in human life forms, thus giving birth to the posthuman, where particular elements have been strengthened. From Simondon's perspective, however, the relationship between humans and machines is, as a synergic ensemble for producing a new individuation, a relationship of "potential energy and effective transducers." So, if the "dynamic partnership" between information and embodiment that Hayles stated above does not simply remain 
an expansion of the mind-body functions of individuals (extension of life or distributed cognition) using technology but can become a relationship that trans-individually realize the pre-individual potential, we may witness another possibility for post-humanity that transcends liberal humanity. The ontological phase of the human race could be phase-shifted from a phase in which liberal humanism was inevitably dominant, or in which "laboring human" individuals dominated over and controlled nature by using technical tools, to a phase of the "posthuman of technological activities," which mutually cooperates with a technical ensemble and adjusts its relationship with the world on the level of transindividual collectivity.

\section{Guattari's Transversality Resonating with Simondon's Transindividuality}

What I would like to add here is that when Simondon's "transindividuality" can be interlocked with the "transversality" of Guattari, the transindividual collectivity for the posthuman society will be able to avoid subjugation. The reason is that while Simondon's transindividuality based on the capability of pre-individual nature and technological object shows a new model of collective individuation, transindividuality doesn't imply any devices for preventing the subjugation of the collective. In fact, for Simondon, the transindividual relationship is essentially emotional. Loneliness and anxiety are inevitable when the "subject" feels the internal pre-individual burden of forcing both breakthrough and transcendence from the pre-existing social relations, and then can only be dissolved when it establishes an affective-emotional relation to the other on the transindividual level. I think that, to prevent the subjugation and fixation of the transindividual collectives based on emotional solidarity, "transversal communication" is indispensable. The transindividual relation, the direct, emotional connection from individual to individual by the medium of technological objects against the pre-existing social orders, in fact, amounts to a mode of transversal communication that, according to Guattari, destroys the pre-existing mode of social relation. Guattari presents a coefficient of transversal communication capable of measuring a group's degree of subjectivization. Guattari's transversality is meaningful as a useful tool for us to be alert to subjugation of Simondon's transindividuality.

Guattari distinguishes non-absolutely between subject groups (actively exploring self-defined projects) and subjugated groups (passively receiving directions) in Psychanalyse et transversalité (1972). If subjugated groups possess self-preserving mechanisms that are characterized by centralism, pyramidal 
hierarchization, and totalization, obstruct the development of creative scission, and are based on the exclusion of other groups, subject groups realize selfrenewal and self-creation in transversal communication that avoids uniform horizontal totality and vertical hierarchy. However, because such a classification is not an absolute one, subject groups are always in danger of being subjugated amidst paranoid convulsions that seek to maintain themselves. The concept of "transversality" is used as a therapeutic and political tool by Guattari in his analytical critique of experimentation with institutional formations of subjectivity at the Clinique de la Borde in France, where he worked. According to Guattari (1972), the hospital is not an institution hierarchically organized simply to treat patients. It is a dynamic arena where meaning and energy intersect between individuals and between groups of disparate levels: at the Clinique de la Borde, Guattari experimented with transversal communication by mixing up and circulating the existing relations of power between doctors and nurses, interns and nurses, nurses and patients, medical and non-medical staff, bureaucrats and unions, and hospital bureaucracies and state funding bodies; he witnessed the production of subjectivity realized by members of the hospital as they engaged in material work (plastic arts, drama, videos, gardening, cooking, horseback riding, pottery, etc.) that hitherto had been inaccessible in their daily lives with new material expressions. He experimented with the producibility of new subjectivity outside the family, linguistic structures, and Oedipal myth, which are psychoanalytic tools, especially by supplanting transference between psychoanalysts and patients with "transversality": if transference is the artificial relation in which the unconscious becomes conscious, transversality is an assemblage of heterogeneous components free from Sigmund Freud's family constellations and Jacques Lacan's official objects of the symbolic order and reveals the desire of the de-individuated subject. As for Guattari's other example, adjusting the blinkers on horses at a racetrack is the "transversality coefficient" (1972, p. 80). When the vision of horses is completely restricted, the degree of transversal communication is low and horses' traumatic collisions increase. By contrast, the more open blinkers are, the higher is the degree of transversal communication and the more harmonious races among horses can be. As with hedgehogs gathered at an appropriate distance to protect themselves from the cold and from one another's spines, the degree of communication that maintains groups is the transversality coefficient. So, the transversality "tends to be realized when communication is maximized between different levels and above all in different directions. It is the object towards which a subject group moves" (Guattari, 1972, p. 80). The transversality is a measure of the communication and openness that produce subjectivity. Transversality within groups is opposed 
to verticality such as pyramidal structures and is opposed also to horizontality, where individuality has disappeared. Transversality seeks to break the fixed wall of identicalness by opening up contact and communication. Subject groups have a high degree of transversality and are open to internal communication and changes. The constitution of complexes of subjectivization is accomplished through "multiple exchanges between individual-group-machine" (Guattari, 1992, p. 7) stemming from such transversal communication.

In short, while Simondon's transindividual subjectivity realizes internal resonance and new solidarity among human individuals, with technical objects as the media, and is based on the common pre-individual, Guattari's transversal subjectivity is a plural and polyphonic, machinic assemblage and based on a rhizomatic connection of heterogeneous things. Though there are differences according to the way of thinking in terms of whether convergence or divergence is emphasized, in that they view communication and the adjustment of the relationship among incompatible and disparate things as a process of subjectivization, "transindividual resonance" and "transversal communication," in the end, are not different situations.

\section{Conclusion}

Consideration of the posthumanization of the human must expand further from the human cyborgization based on the anthropo-individual-centric liberal humanism. According to Simondon's perspective, the causal interactions and mutual regulation between "ensembles of technical objects" that construct convergence networking through information technology and "transindividual human groups" that realize emotional sympathy and internal resonance which is maintained by a high degree of transversal communication, and their co-evolution may very well be the image of posthumanizing society. From such a philosophical perspective, the task of critically deconstructing what severs, hinders, and distorts the interrelationships among the "preindividual," "transindividual," and "technological" will be the primary condition for the production of posthuman subjectivization. According to the thought shared by Simondon and DeleuzeGuattari, every form is meta-stable and a compound of relations between forces. The form of human has not always existed and will not exist forever. Human beings were produced in the disciplinary society in the form of selfdisciplined "individuals" and have been produced in the control society in the form of de-individualized "dividuals," respectively. If so, then what will the form of human beings be in the post-human society outside or after the control society, which has yet to arrive? How would it be if it were to be the form of 
"transindividuals" based on an ensemble of nature and technology? It will be possible for posthuman society based on technology to be produced when the liberal humanism of cyborgization - whose sole purpose is to strengthen human individuals' capacity - is overcome, transindividual relationships that form solidarity through the pre-individual potential are realized, and a high degree of transversal communication that prevents the subjugation of this collectivity is maintained.

\section{References}

BOGARD, W. "Deleuze and Machines: A Politics of Technology?" (pp. 15-31). Deleuze and New Technology. Edinburgh: Edinburgh Univ. Press, 2009.

DELEUZE, G. Différence et Répétition. Paris: PUF, 1968.

. "On the Death of Man and Superman". (pp. 124-132). In: Foucault. Trans. Seán Hand. Minneapolis: Univ. of Minnesota Press, 1988.

. "Control and Becoming". (pp. 169-176). In: Negotiations 1972-1990. Trans. Martin Joughin. New York: Columbia Univ. Press, 1995.

. "Postscript on the Societies of Control". (pp. 177-182). In: Negotiations $1972-$ 1990. Trans. Martin Joughin. New York: Columbia Univ. Press, 1995.

DELEUZE, G., GUATTARI, F. Mille Plateaux: Capitalisme et Schizophrénie. Paris: Minuit, 1980.

. Anti-Oedipus: Capitalism and Schizophrenia. Trans. Robert Hurley, Mark Seem, and Helen R. Lane. Minneapolis: Univ. of Minnesota Press, 1983.

GUATTARI, F. Psychanalyse et transversalité. Paris: Maspero, 1972.

. Chaosmosis: An Ethico-Aesthetic Paradigm. Sydney: Power Publication, 1992. HAYLES, K. How We Became Posthuman: Virtual Bodies in Cybernetics, Literature, and Informatics. Chicago: University of Chicago Press, 1999.

KURZWEIL, R. The Singularity is Near: When Humans Transcend Biology. Viking, 2005.

MORAVEC, H. Mind Children: The Future of Robot and Human Intelligence. Harvard University Press, 1990.

MORE, M., VITA-MORE, N. (eds.). The Transhumanist Reader. Oxford: WileyBlackwell, 2013.

SIMONDON, G. (1958). Du Mode d'existence des objets techniques. Paris: Aubier, 1989. . (1958). L'Individuation à la lumière des notions de forme et d'information. Grenoble: Millon, 2005. 